\title{
MOLECULAR CLONING OF STRESS-INDUCED GENES OF MAIZE (ZEA MAYS L.) USING THE PCR-SELECT CDNA SUBTRACTION TECHNIQUE
}

\author{
THUY HA NGUYEN \\ Institute of Agricultural Genetics, Hanoi, Vietnam \\ JỨRG LEIPNER, PETER STAMP \\ Institute of Plant Sciences, Switzerland \\ ORLENE GUERRA-PERAZA \\ University of Guelph, Canada
}

\begin{abstract}
Environmental abiotic stresses, such as drought, high-salinity and low temperature, severely impair plant growth and development and limit crop productivity. In order to survive and adapt to these stresses, plants must induce various physiological, bichemical and molecular changes, including the adaptation of the photosynthetic apparatus, changing in the membrane lipid, the activation of calcium influxes and $\mathrm{Ca} 2+-d e p e n d e n t$ protein kinase cascades, the accumulation of proline, glycine betaine, soluble sugars and increasing the levels of antioxidants. All these changes are accompanied by notable increases or decreases in the transcript level of specific genes. Hence, transcriptional control of stressregulated genes is a crucial part of plant responses to abiotic stresses; a further characterization of such gene transcripts in plants may help us to understand the molecular basis of the plant response to abiotic stresses and to identify new targets for manipulating biochemical, physiological and developmental processes in plants.

To clarify the process of the response of maize to cold stress and to discover maize genes associated with the response pathway(s), genes induced by cold treatment were isolated according to the PCR-select cDNA subtraction method. 18 cold-induced genes $(\mathrm{ZmCOI})$ were detected at $6 \square \mathrm{C}$. They were divided into 6 groups, based on their functions. The cold induction of these genes was confirmed by reverse transcriptase-polymerase chain reaction (RT-PCR) analyses.

The sequences of these 18 cold-induced genes have been deposited in GenBank under accesion numbers
\end{abstract} from DQ078760 to DQ078778.

\section{INTRODUCTION}

Environmental abiotic stresses, such as drought, high-salinity and low temperature, severely impair plant growth and development and limit crop productivity. In order to survive and adapt to these stresses, plants must modulate various physiological and metabolic responses based on the stress signals. Hundreds of genes to be involved in abiotic stress responses [11]. These genes function not only in directly protecting cells against stress conditions but also in the regulation of gene expression and signal transduction in abiotic stress responses. Multiple molecular regulatory mechanisms appear to be involved in the different stress signal pathways $[4,11,14]$.

Low temperature is one of the most important abiotic factors limiting growth, development and distribution of plants. Maize (Zea mays L.) originates in subtropical regions and is known to be very sensitive to low growth temperature. The optimal growth temperatures for maize lay between $30 \square \mathrm{C}$ to $35 \square \mathrm{C}$. Low temperature affects germination, seedling growth, early leaf development and overall maize crop growth and productivity. In the temperate regions, maize is often exposed to low temperature during its early development 
resulting in poor photosynthetic performance associated with retarded plant development [7].

Although much of knowledge in cold acclimation arises from Arabidopsis thaliana it is important to research directly in the cold sensitive crops to unravel its precise response pattern. Maize is sensitive to low temperature, however, it has the ability to acclimate to suboptimal temperature (about 14 to $20 \square \mathrm{C}$ ) and, thus, to increase its tolerance to cold stress [7]. The response to low temperature is accompanied with changes in specific gene transcripts and in protein activity. The identity of some genes is known such as phenylalanine ammonialyase, ZmDREB1A, ZmDBF1, ZmCDPK1, MLIP15, FAD7, FAD8, BADH and ZmPLC1 [10, 13, 15, 16]. However, the exact function of these genes and encoded proteins in the cold response in maize remains not fully understood although it is known that some of their orthologues are important for the stress response in other plant species. Increased knowledge about the components of the stress response might present new strategies to render agriculturally important plants like maize for a higher stress tolerance.

To increase the understanding of cold stress response in maize, a PCR-select cDNA subtraction method, also known as suppression subtractive hybridization ( $\mathrm{SSH}$ ), was selected to profile genes whose expression increases upon cold stress at $6 \square \mathrm{C}$. We identified a group of novel genes induced by cold stress where the majority of genes shared similarity on the amino acid level with known proteins in other plant species.

\section{MATERIALS AND METHODS}

\section{Plant material and growth conditions}

Maize seeds of the genotype ETH-DH7 were grown in half strength Hoagland solution (H2395, Sigma Chemical Co.) supplemented with $0.5 \% \mathrm{Fe}$-sequestrene, $6 \mathrm{mM} \mathrm{K}^{+}$and $4 \mathrm{mM}$ $\mathrm{Ca}^{2+}$ or in $1 \mathrm{~L}$ pots containing a commercial mixture of soil, peat and compost (Topf und Pikiererde 140, Ricoter, Aarberg, Switzerland). Plants were grown until the third leaf was fully developed at 25/22 $\square \mathrm{C}$ (day/night) in growth chambers (Conviron PGW36, Winnipeg, Canada) at a 12-hour photoperiod, a light 78 intensity of $300 \mu \mathrm{mol} \mathrm{m} \mathrm{m}^{-2} \mathrm{~s}^{-1}$ and a relative humidity of $60 / 70 \%$ (day/night).

\section{PCR-select cDNA subtraction method}

RNA preparation, PCR-based subtraction
and cloning

Total RNA was isolated from the third leaf using TRIZOL ${ }^{d}$ according to Sigma's instructions for RNA isolation. The PCR-based cDNA subtraction was performed by using a PCR-Select cDNA Subtraction Kit (Clontech, Mountain View, CA, USA) according to manufacturer's instructions. "Tester" (plant treated at $6 \square \mathrm{C}$ for 48 hours) and "driver" (plant grown at $25 \square \mathrm{C}$ ) double-stranded cDNAs were synthesized from mRNA using the PCR cDNA Synthesis Kit (Clontech, Mountain View, CA, USA). Double-stranded cDNAs were digested with RsaI and the digested tester cDNA was ligated with Adapter 1 and $2 \mathrm{R}$ provided in the kit.

\section{Subtractive hybridization}

To obtain differentially expressed cDNAs, two rounds of hybridizations were performed. The purpose of the first round hybridization was to equalize and to enrich the differentially expressed sequences. The objective of the second round was to produce double-stranded tester molecules with different adaptors on each end. Each of the adapter-ligated cDNAs was heat-denatured and annealed to excess heatdenatured driver cDNA (first hybridization). The two samples from the first hybridization were combined and a fresh portion of heatdenatured excess driver cDNA was added (second hybridization).

\section{Suppression of PCR amplification and cloning of subtracted cDNA}

Two rounds of PCR amplifications were performed for the subtracted cDNA. In the first amplification, PCR was suppressed; whereby only differentially expressed sequences were amplified exponentially. In the second procedure, the background was reduced to enrich the differentially expressed sequences. Each PCR product was analyzed on a $2.0 \%$ agarose/EtBr gel. All of the primers (PCR primer 1 and nested PCR primers 1 and 2R) for 
the PCR were provided in the kit (Clontech, Mountain View, CA, USA). The subtracted cDNAs obtained from the second PCR amplification were cloned into pDrive vector (QIAGEN GmbH, Hilden, Germany). The transformed cells were plated onto LB agar culture plates containing ampicillin. Thus, a subtracted cDNA library was constructed.

Differential screening of the subtracted cDNA library and DNA sequencing

Dot blot hybridization was performed with PCR-Select Differential Screening Kit (Clontech, Mountain View, CA, USA). A total of 2000 clones were selected and grown. Bacterial cultures were used to amplify cDNA insert by PCR. The amplified cDNA was blotted onto Hybond Blotting nylon membrane (Amersham Biosciences, Piscataway, NJ, USA). The membrane was hybridized with doublestranded cDNA pools of equal specific activity derived from the subtracted or un-subtracted tester mRNA in DIG-Easy hybridization buffer for 15-18 hours at $72 \square \mathrm{C}$. Membranes were washed in $2 \times \mathrm{SSC}, 0.1 \%$ SDS for $2 \times 5$ minutes at room temperature, $0.1 \times \mathrm{SSC}, 0.1 \% \mathrm{SDS}$ for 2 $\times 15$ minutes at $75 \square \mathrm{C}$ and then exposed to Xray films. The signals of corresponding clones from two hybridizations were compared and the positive cloned were selected. All the positive clones were sequenced with SP6/T7 primer (Roche, Basel, Switzerland) by MWG (MWGBiotech AG, Germany).

\section{Reverse transcriptase (RT)-PCR of detected cDNA sequences}

RT-PCR analysis was carried out to confirm differential expression of the detected sequences, which were found by the above PCR-select cDNA subtraction method. First, total RNA was extracted from maize leaf samples using Tri Reagent ${ }^{\mathrm{d}}$ according to Sigma's protocol for RNA isolation. Then, total RNA of each sample was reverse transcribed to firststrand cDNAs using oligo $(\mathrm{dT})_{23}$ primer according to the supplier's instructions (Advantage RT-for-PCR Kits, DB Biosciences, Clontech, Mountain View, CA, USA). The cDNA was amplified by PCR using the specific primers. The maize coding gene ubiquitin ZmUBI (accession number S94466) was used as internal standard. Amplified PCR products were electrophoresed using 2.0\% (w/v) Agarose gel.

\section{Bioinformatics}

A similarity search was performed using the basic local alignment search tool (BLAST) (National Centre for Biotechnology Information (NIH, Bethesda, MD, USA) (http://www.ncbi. nlm.nih.gov/BLAST/) and the NCBI BLAST2 service maintained by the Swiss Institute of Bioinformatics (http://au.expasy.org/tools/ blast/).

\section{RESULTS}

\section{Cloning and identification of cold- induced cDNAs}

To identify cold-induced ( $\mathrm{ZmCOI}$ ) genes in maize (genotype ETH-DH7), seedlings were exposed to cold stress. Total RNA was extracted from the third leaf before and after 48 hours of exposure to $6^{\circ} \mathrm{C}$. The cDNA, amplified by the PCR-select cDNA subtraction method, was cloned and screened using $50 \mu \mathrm{l}$ of bacteria cultures. Each clone was spotted onto two identical nylon membranes and hybridized with tester cDNA probe from plants exposed to $6 \square \mathrm{C}$ for 48 hours and control cDNA from plant grown at $25 \square \mathrm{C}$ (fig. 1). Sixty-nine candidate clones were obtained as cold-inducible and produced a strong signal when probed with cDNAs derived from cold-treated plants (fig. $1 \mathrm{~B}$ ), as compared to control cDNA (fig. 1A). These 69 clones were sequenced.

\section{Identification of homology sequences of 69 candidate cold-induced cDNAs}

The 69 clones were sequenced and annotated in the GenBank database (table 1). For some sequences a high percentage of replications were identified resulting in 22 different cDNA sequences. Furthermore, the search for highly similar expressed sequence tagged (EST) by BLAST revealed that four cDNA sequences (ZmCOI6.1a, ZmCOI6.1b, $\mathrm{ZmCOI6.1c}$ and $\mathrm{ZmCOI6.1d)}$ and two cDNA sequences ( $\mathrm{ZmCOI6.7a}$ and $\mathrm{ZmCOI6.7b)}$ probably originated from the same mRNA ZmCOI6.1 and ZmCOI6.7, respectively (fig. 2). 


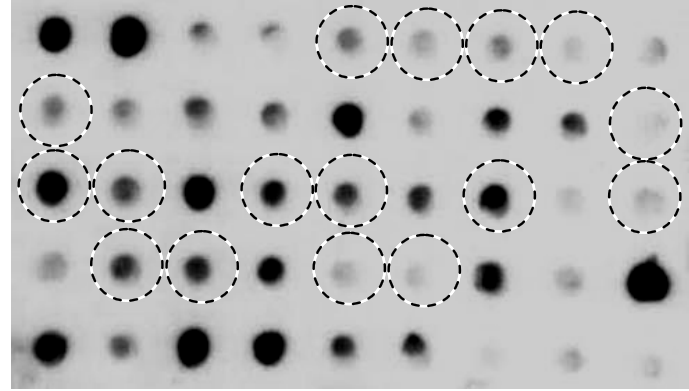

(A) Non-treated

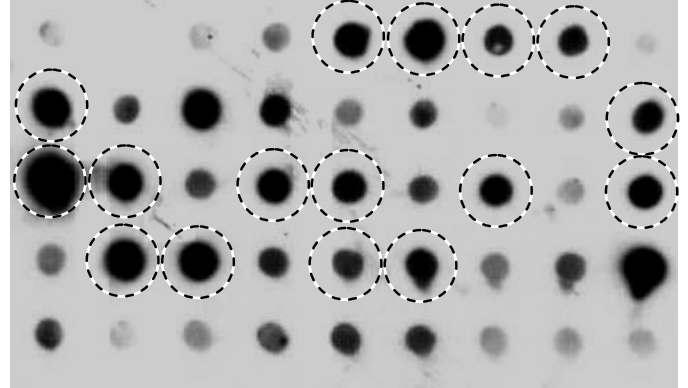

(B) Cold-treated

Figure 1. Example of the differential screening of cold-induced genes by colony-DNA dot blot

Bacterial culture was dot-blotted on two nylon membranes and hybridized with a probe of cDNA prepared from control plants grown at $25 \square \mathrm{C}$ (A) and with a probe of cDNA obtained from plants treated at $6 \square \mathrm{C}$ for 48 hours (B). Cold-induced candidates are marked by circles.

The 18 defined individual sequences represented mostly novel not yet characterized genes in maize. The candidate genes were named ZmCOI6 (Zea mays cold induced at $6 \square$ C) followed by a number. To unravel potential function, a similarity search was performed using the basic local alignment search tool (BLAST) for identification of homologue/orthologue sequences using the deduced amino acid sequence of the $\mathrm{ZmCOI}$ genes. Of the 18 candidate clones, 16 code for polypeptides with a high degree of similarity with known or putative polypeptides from maize (5 sequences) or from other plants species mostly from Oryza sativa (table 1 and fig. 2). For most sequences, the shared similarity did not comprise the whole homolog/ortholog sequence. However, a new name was given to most of the $\mathrm{ZmCOI}$ sequences according to the function of their homolog or orthologue protein e.g. $\mathrm{ZmCOI6.10}$ was similar to a $\mathrm{Ca}^{2+}$ ATPase and was therefore given the name $Z m A C A l$ (table).

The ZmCOI6.20 and ZmCOI6.21 share similarity with two different transcription factors, namely the DRE/CRT-binding protein 2A (ZmDREB2A) and the ethylene-responsive element binding factor 3 (OsERF3) of rice, respectively (table 1 and fig. 2). To define the exact classification of ZmCOI6.21, we identified an identical maize nucleotide sequence in the PlantGDB. The cDNA ZmCOI6.21 was very similar $\left(1 \cdot \mathrm{e}^{-172}\right)$ to the contig sequence ZmGSStuc 11-12-04.4500.2. The ZmCOI6.21 nucleotide sequence was 80 substituted in silico for this sequence. The alignment of the AP2 binding domain of the substituted $Z m$ COI6.21 against ERF/AP2 proteins proved the evidence that ZmCOI6.21 was part of the sequence of an ERF3-type protein of maize and consequently was designated as ZmERF3. No similar sequence was found for the deduced amino acid sequences of ZmCOI6.5, ZmCOI6.16 and $\mathrm{ZmCOI6.18.} \mathrm{However,} \mathrm{further} \mathrm{analysis} \mathrm{revealed}$ that $\mathrm{ZmCOI6.5}$ DNA sequence was a perfect match with the maize EST CD999796 3'-UTR flanking region. The deduced amino acid sequence of this CD999796 EST was highly similar to the phosphoribulokinase of wheat (Triticum aestivum L.). ZmCOI6.16 DNA sequence showed $97 \%$ identity with the maize EST AY108897 3'-UTR region. The deduced amino acid sequence of AY108897 contained a rubrerythrin motif and an ACSF (aerobic cyclase system, Fe-containing subunit) domain showing high similarity to the aerobic $\mathrm{Mg}$ protoporphyrin IX monomethyl ester cyclase from Hordeum vulgare (83\% identity).

As a result of the above describe analysis, genes were grouped into six broad categories based on putative function (table 1). The first group: linked to photosynthesis are $\mathrm{ZmCOI6.5}$ (ZmPRK), ZmCOI6.9 (ZmMel), ZmCOI6.15 $(\mathrm{ZmrbcL})$ and $\mathrm{ZmCOI6.16}$ suggesting a remodelling of the photosynthesis to adapt to changed growth conditions to reduce waste of resources. The second group: related to signalling and regulation of gene transcription is including ZmCOI6.2, ZmACAl, ZmCOI6.14, 
ZmDREB2A and ZmERF3 suggesting the role of signal transduction of stimuli into the cell for a response and as a result changes in transcription by transcription factors. The third group: stress response regulators including ZmCOI6.3, $\mathrm{ZmCOI6.8}$ and $\mathrm{ZmCOI6.19}$. The fourth group:
$\mathrm{ZmCOI6.12}(\mathrm{ZmOPRl})$ is associated with the systemic response to stress. Regulation of metabolism including $\mathrm{ZmCOI6.4,} \mathrm{ZmCOI6.6}$ and $\mathrm{ZmCOI6.13}$ is the fifth group. The sixth group contain genes that codes for proteins with unknown function.
(1)

ZmCOI 6.1 Q94LK4

ZmCOI 6.1 Q94LK4

ZmCOI6.1 Q94LK4

ZmCOI 6.1 Q94LK4

ZmCOI 6.1 Q94LK4

ZmCOI 6.1 Q94LK4

ZMCOI 6.1 Q94LK4

(2)

ZmCOI 6.3 Q6ETQ7

ZMCOI 6.3 Q6ETQ7

(3)

ZmCOI 6.3 Q8GS33

ZmCOI 6.3 Q8GS33 ZMCOI 6.3 Q8GS33

(4)

ZMCOI 6.5 P 49076

ZMCOI 6.5 P49076

(5)

ZmCOI 6.6 Q689G6

ZmCOI 6.6 Q689G6

ZMCOI 6.6 Q689G6

ZmCOI 6.6 Q689G6

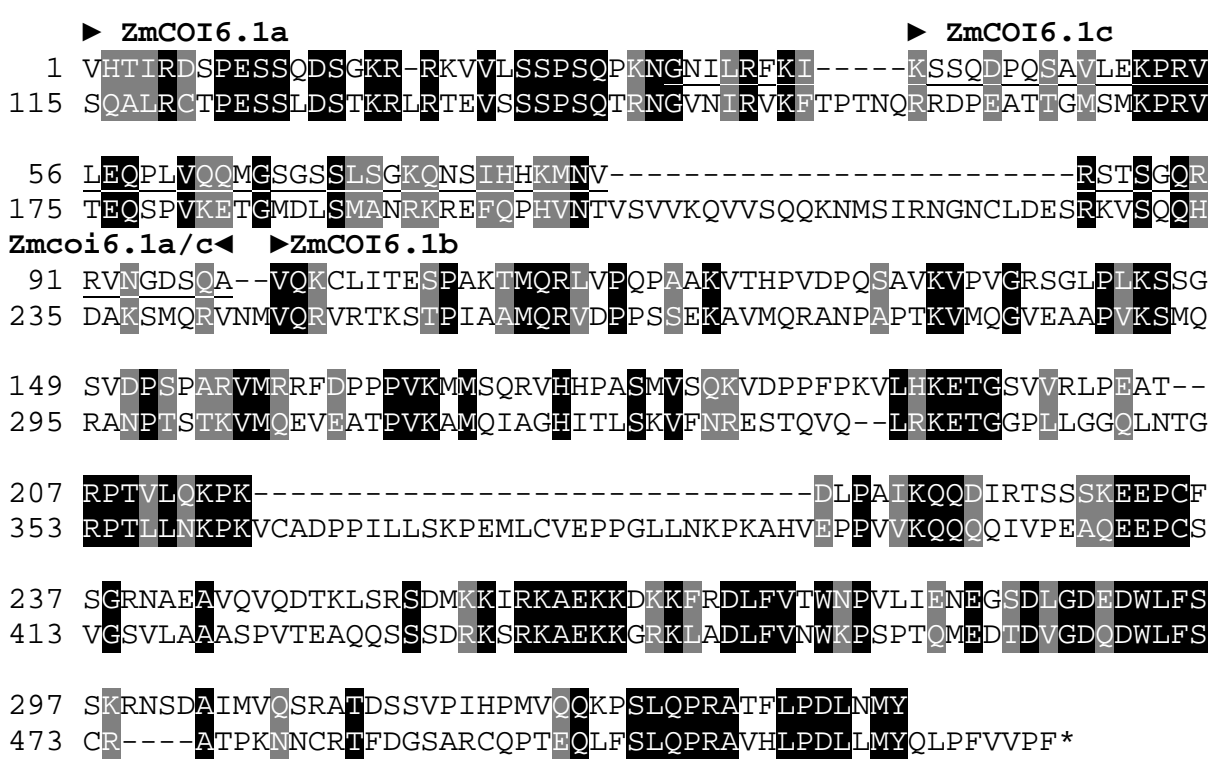

1 LYNGEDKNGFLKKLILKFKDPENTTLI ILDKFDGNSELAAELVTANGYKAAFAVKDGAEG 176 PYDGEDKNGF LKKLSLRF KDP ENTTLVILDKF DGNSELVAELVTANGYKAAFAVKDGAEG 61 SRGWKSSNLPWKAPPKGF SFDLGELFGDGSD

236 RRGWLSSSLPWTAPKKGFS--LSDLIGDGTD->

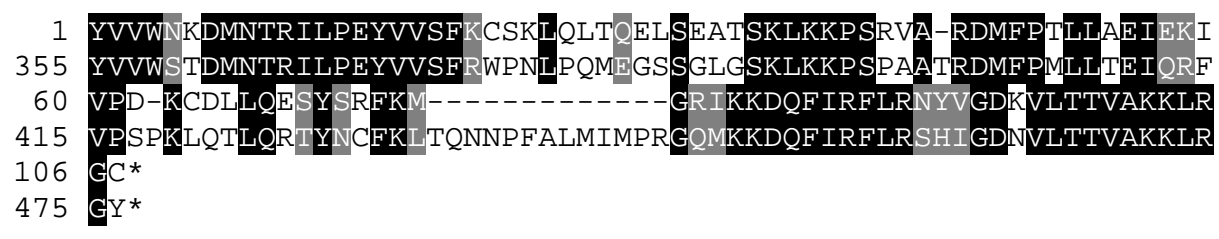

1 KNISFTVWDVGGQDKIRP LWRHYFQNTQGLIFVVDSNDRDRVVEARDELHRMLNEDGLRD

58 KNISFTVWDVGGQDKIRP LWRHYFQNTQGLIFVVD SNDRDRVVEARDELHRMLNEDELRD

60 AVLLVF ANKQDLP NAMNAAE I TDKLGLHSLRQRHWY

118 AVLLVFANKQDLPNAMNAAEITDKLGLNSLRQRHWY $\rightarrow$

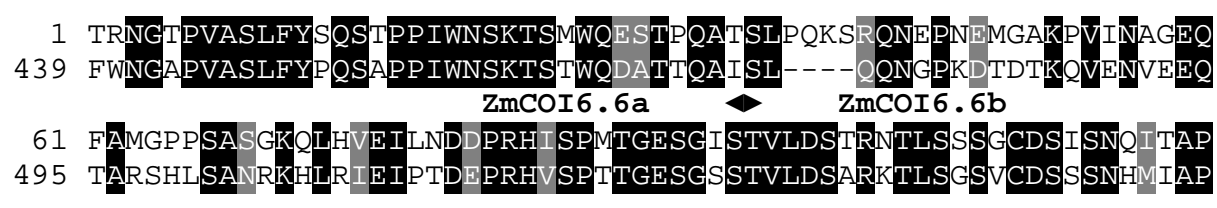

121 TESSNVYKDVPETPSAEGSRHLSQREAALNKFRLKRKDRCFEKKVRYQSRKLLAEQRPRV 555 TESSNV---VPENP--DGLRHLSQREAALNKFRLKRKDRCFEKKVRYQSRKLLAEQRPRV

181 KGQFVRQDHSIQGSGPVTELELYS I IKSHCKLHCGLRVSWMS *

610 KGQFVRQDHGVQGS* 
(6)

ZMCOI 6.8 Q6AT93

(7)

ZMCOI 6.8

Q84LP 6

ZmCOI 6.8

Q84LP 6

ZMCOI 6.8

Q84LP 6

ZmCOI 6.8

Q84LP 6

ZMCOI 6.8

Q84LP 6

(8)

ZmCOI 6.9

Q94IN2

ZmCOI 6.9

Q94IN2

(9)

ZmCOI 6.10

Q8H9F 1

ZmCOI 6.10

Q8H9F 1

(10)

ZmCOI 6.12

081230

ZmCOI 6.12

081230

(11)

ZmCOI 6.13

$\mathrm{P} 00874$

ZmCOI 6.13

$\mathrm{P} 00874$

(12)

ZMCOI 6.16

Q9AVA 6

ZMCOI 6.16

Q9AVA 6

(13)

ZmCOI 6.17

Q5MGQ8

(14)

ZMCOI 6.18 Q9LRF 3

ZMCOI 6.18

Q9LRF 3
1 GCGHEFWICLLLTFLGYIPGI IYAIYAITKNN *

26 GCGHEFWICLLLTFLGYIPGIIYAIYAITK*

1

279

61

339

121

399

181

459

241

519

TNNEKLLNDEFYIGLRQKRATGEEYDELIEEFMSAVKQFYGEKVLIQFEDFANHNAFDLI

TNNEKLLNDEFY IGLRQKRATGEEYDELIEEFMSAVKQFYGEKVLIQFEDF ANHNAFDLL

EKYSKSHLVFNDDIQGTASVVLAGLLAALKMVGGTLAEQTYLFLGAGEAGTGIAELIALE

EKYSKSHLVFNDD IQGTASVVIAGLLAALKMVGGTLAEQTYLF LGAGEAGTGIAELIALE

I SKQTNAP IEECRKKVWLVDSKGLIVDSRKGSLQP FKKPWAHEHEP LKTLYDAVQS IKPT

I SKQTNAP LEECRKKVWLVDSKGLIVDSRKGSLQP FKKPWAHEHEP LKTLYDAVQS IKP T

VLIGT SGVGRTF TKE I IEAMS SFNERP I IFS LSNP TS HSECTAEQAYTWSQGRS IF ASGS

VLIGTSGVGRTF TKE I IEAMSSFNERP I IF S LSNP TS HSECTAEQAYTWSQGRS IFASGS

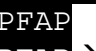

$\mathrm{PFAP} \rightarrow$$$
48
$$
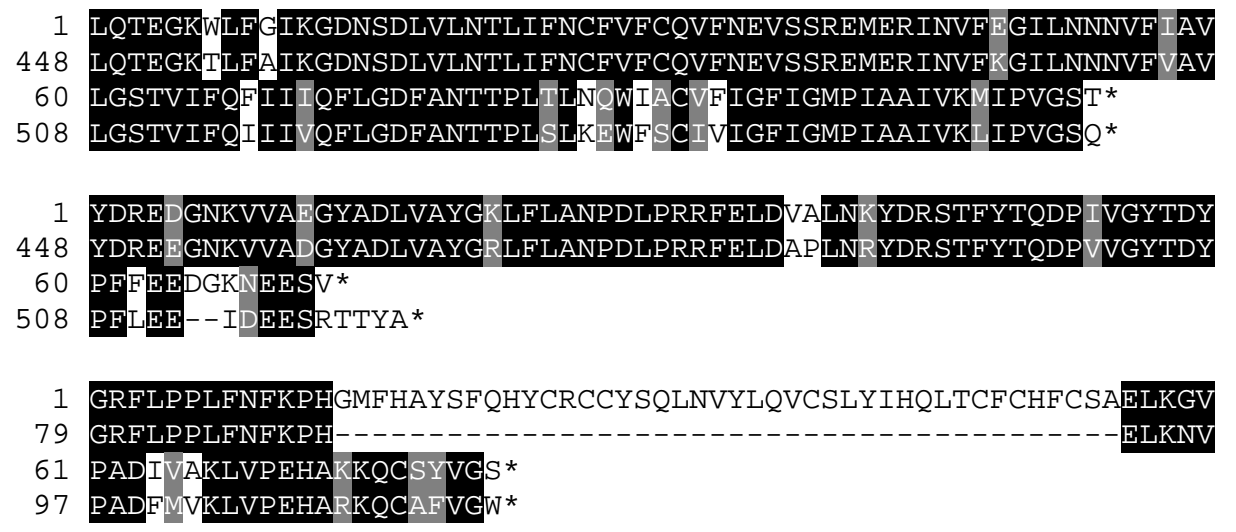

Figure 2. The predicted $Z m C O I$ amino acid sequences from (1) to (18) aligned to their closest homolog/ortholog. Deduced amino acid sequences of $\mathrm{ZmCOI}$ were compared for similar or identical amino acids. Dashed lines (gaps) are included to optimize alignment. Similar or identical amino acids are coloured in grey and black respectively. Numbers beside sequences do not reflect the actual size of sequences. ZmCOI6.1 is represented by several fragments that comprise together a more complete sequence and is used for the alignment. Homolog or ortholog sequence is represented by accession number. $\$$ and 4 , indicates the start and end of $\mathrm{ZmCOI}$ fragment sequence, respectively; *. stop codon; $\rightarrow$. that the sequence continues but is not represented. Analysis of sequences was performed with Clustal W. 
List of up-regulated transcripts in response to cold stress in maize leaf tissue

\begin{tabular}{|c|c|c|c|c|c|}
\hline \multicolumn{3}{|c|}{ cDNA } & \multicolumn{3}{|c|}{ Similarity search result (blast at NCBI) } \\
\hline Name & $\begin{array}{c}\text { size } \\
b p\end{array}$ & $\begin{array}{c}\text { GenBank } \\
\text { accession } \\
\end{array}$ & Annotation (Species) & $\begin{array}{c}\text { GenBank } \\
\text { accession }\end{array}$ & E-value \\
\hline \multicolumn{6}{|c|}{ Group I - Photosynthesis related } \\
\hline $\begin{array}{l}\mathrm{ZmCOI6.5} \\
(\mathrm{ZmPRK}) \\
\end{array}$ & 208 & DQ078762 & ${ }^{\mathrm{a}}$ Phosphoribulokinase (T. aestivum) & CAB56544 & \\
\hline $\begin{array}{l}\text { ZmCOI6.9 } \\
(\mathrm{ZmMel})\end{array}$ & 575 & DQ078766 & NADP-malic enzyme (Z. mays) & AAP33011 & $7 \cdot \mathrm{e}^{-123}$ \\
\hline $\begin{array}{l}\mathrm{ZmCOI6.15} \\
(\mathrm{ZmrbcL})\end{array}$ & 216 & DQ078772 & $\begin{array}{l}\text { Ribulose-1,5-bisphosphate } \\
\text { carboxylase/oxygenase } \\
\text { subunit }(\text { Z. mays) }\end{array}$ & CAA78027 & $3 \cdot e^{-36}$ \\
\hline $\mathrm{ZmCOI6.16}$ & 261 & DQ078773 & $\begin{array}{l}\text { b Aerobic } \text { Mg-protoporphyrin IX } \\
\text { monomethyl ester cyclase }(H \text {. vulgare })\end{array}$ & AAW80518 & \\
\hline \multicolumn{6}{|c|}{ Group II - Signalling and regulation of gene transcription } \\
\hline $\begin{array}{l}\mathrm{ZmCOI6.2a} \\
\mathrm{ZmCOI6.2b}\end{array}$ & $\begin{array}{l}273 \\
658\end{array}$ & $\begin{array}{l}\text { DQ082731 } \\
\text { DQ078764 }\end{array}$ & $\begin{array}{l}\text { Peudo-response regulator-like }(O \text {. } \\
\text { sativa) }\end{array}$ & BAD46270 & $\begin{array}{l}4 \cdot e^{-20} \\
6 \cdot e^{-36}\end{array}$ \\
\hline $\begin{array}{l}\mathrm{ZmCOI6.10} \\
(\mathrm{ZmACA1})\end{array}$ & 437 & DQ078767 & $\begin{array}{l}\text { Calcium-transporting ATPase } 2 \text {, } \\
\text { plasma membrane-type }(O \text {. sativa })\end{array}$ & ABF94528 & $1 \cdot e^{-53}$ \\
\hline $\mathrm{ZmCOI6.14}$ & 364 & DQ078771 & $\begin{array}{l}\text { Shaggy-related protein kinase } \\
\text { gamma }(O . \text { sativa })\end{array}$ & BAB40983 & $4 \cdot e^{-8}$ \\
\hline $\begin{array}{l}\mathrm{ZmCOI6.20} \\
(\mathrm{ZmDREB} 2 \mathrm{~A})\end{array}$ & 311 & DQ078777 & $\begin{array}{llr}\text { ERF/AP2 } & \text { domain } & \text { containing } \\
\text { transcription } & \text { factor } & (\mathrm{ZmDREB} 2 \mathrm{~A}) \\
(\text { Z. mays }) & & \\
\end{array}$ & BAE96012 & $3 \cdot e^{-4}$ \\
\hline $\begin{array}{l}\mathrm{ZmCOI6.21} \\
(\mathrm{ZmERF3})\end{array}$ & 455 & DQ078778 & $\begin{array}{ll}\text { Ethylene-responsive } & \text { element } \\
\text { binding factor 3 }(O \text {. sativa }) & \\
\end{array}$ & NM_190908 & $3 \cdot e^{-8}$ \\
\hline \multicolumn{6}{|c|}{ Group III - Stress response regulators } \\
\hline $\mathrm{ZmCOI6.3}$ & 321 & DQ078760 & $\begin{array}{l}\text { Hydroxyproline-rich glycoprotein- } \\
\text { like }(O \text {. sativa })\end{array}$ & BAD27963 & $2 \cdot \mathrm{e}^{-36}$ \\
\hline $\mathrm{ZmCOI6.8}$ & 220 & DQ078765 & $\begin{array}{l}\text { Hydrophobic protein LTI6B }(O . \\
\text { sativa) }\end{array}$ & Q6AT93 & 0.043 \\
\hline $\mathrm{ZmCOI6.19}$ & 444 & DQ078776 & $\begin{array}{l}\text { Putative selenium binding protein } \\
(\text { O. sativa })\end{array}$ & NP_914832 & $9 \cdot \mathrm{e}^{-42}$ \\
\hline \multicolumn{6}{|c|}{ Group IV - Systemic response to stress } \\
\hline $\begin{array}{l}\mathrm{ZmCOi6.12} \\
(\mathrm{ZmOPRl}) \\
\end{array}$ & 336 & DQ078769 & $\begin{array}{l}12-\text { Oxo - phytodienoic acid } \\
\text { reductase } 1(\text { (Z. mays) }\end{array}$ & AAY26521 & $2 \cdot e^{-35}$ \\
\hline \multicolumn{6}{|c|}{ Group V - Regulation of metabolism } \\
\hline $\mathrm{ZmCOI6.4}$ & 433 & DQ078761 & $\begin{array}{l}\text { Poly polymerase catalytic domain } \\
\text { containing protein }(O \text {. sativa })\end{array}$ & ABF94778 & $7 \cdot e-29$ \\
\hline $\mathrm{ZmCOI6.6}$ & 448 & DQ078763 & ADP-ribosylation factor $(O$. sativa $)$ & XP_470055 & $5 \cdot e^{-50}$ \\
\hline $\mathrm{ZmCOI6.13}$ & 519 & DQ078770 & 23S ribosomal RNA (Z. mays) & $\mathrm{X} 01365$ & 0 \\
\hline \multicolumn{6}{|c|}{ Group VI - Genes with unknown function } \\
\hline $\begin{array}{l}\mathrm{ZmCOI6.1a} \\
\mathrm{ZmCOI6.1b} \\
\mathrm{ZmCOI6.1c} \\
\mathrm{ZmCOI6.1d}\end{array}$ & $\begin{array}{l}320 \\
716 \\
203 \\
128\end{array}$ & $\begin{array}{l}\text { (DQ060243) } \\
\text { (DQ060243) } \\
\text { DQ078768 } \\
\text { DQ078774 }\end{array}$ & Expressed protein (O. sativa) & ABF94896 & $\mathrm{c} 7 \cdot \mathrm{e}^{-67}$ \\
\hline ZmCOI6.18 & 726 & DQ078775 & No similarity & & \\
\hline
\end{tabular}

Note: ${ }^{a}=$ versus similarity to the EST CD999796; ${ }^{\mathrm{b}}=$ versus similarity to the EST AY $108897 ;{ }^{\mathrm{c}}=$ for the whole fragment (DQ060243). 


\section{Confirmation of identified cold-induced genes by RT-PCR}

To determine whether the identified genes were indeed differentially expressed in $6 \square \mathrm{C}$ treated plants, an RT-PCR analysis was performed. The third leaf of plants exposed to $6 \square \mathrm{C}$ for 48 hours and the third leaf of control plants grown at $25 \square \mathrm{C}$ were collected. The first strand-cDNAs were synthesized $(1.5 \mu \mathrm{g})$ from total RNA derived from treated and control plants. Five clones, which were detected by the PCR-select cDNA subtraction method, were taken. These five clones were replicated frequently in the library (ZmCOI6.1 $a$ and $\mathrm{ZmCOI6.1b)}$ or were similar to stress-induced genes (ZmCOI6.12, ZmCOI6.20, ZmCOI6.21).

The RT-PCR results indicate that the PCRselect cDNA subtraction method detects genes (ZmCOI6.1a, ZmCOI6.1b, ZmCOI6.12, $\mathrm{ZmCOI6.20}$ and $\mathrm{ZmCOI6.21),} \mathrm{which} \mathrm{were} \mathrm{up-}$ regulated in cold-treated plant transcripts, in contrast to the transcripts of control plants (fig. 3), whereas there were no or only low detectable $\mathrm{ZmCOI}$ transcripts in the control maize leaf. In the $6 \square \mathrm{C}$-cold-treated samples, transcripts were induced at 48 hours after treatment (figure 3) and confirm the results of PCR-select cDNA subtraction.

\section{DISCUSSION}

The variety of signalling pathways affected by abiotic stress illustrates the complexity of plant stress response $[4,6,15,16]$. For the objective to further characterize these pathways transcriptional regulation studies have been proven to be very important $[11,15,16]$. We present the identification of 18 genes whose expression was induced or increased in maize seedlings upon long cold stress treatment (48 hours). For several genes orthologue sequences were found in different plant species such as rice, barley, Arabidopsis and millet suggesting that these genes are conserved. It remains to be examined if the stress induction and/or function are conserved between species.

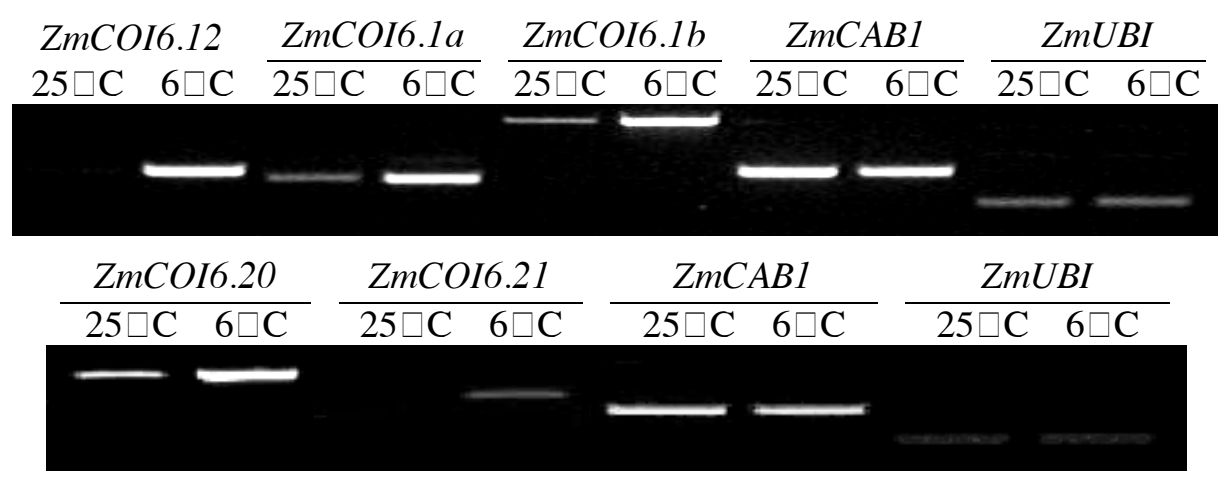

Figure 3. Cold-induced genes ZmCOI6.1a, ZmCOI6.1b, ZmCOI6.12, ZmCOI6.20 and ZmCOI6.21 are induced by cold treatment of maize seedlings. RT-PCR was performed with the specific primers listed in Table A.1 using DNA derived from RNA extracted from 6 $\square$ C-treated plants and control plants grown at $25 \square \mathrm{C}$. Maize ubiquitin (ZmUBI) and maize chlorophyll a/b binding protein (ZmCAB1) are internal controls.

The 18 found genes could be grouped in six categories (Table 1) showing their diverse function. These genes were linked to photosynthesis, to signalling and regulation of gene transcription, to stress response regulation, to systemic response to stress. In addition, there was a sixth group that contains genes coding for proteins with unknown function. The diverse function of the genes found in this study is an indication of the complexity and the amount of different pathways involved in cold stress response in maize as shown also for other plants $[4,6]$.

The deduced amino acid sequence of the differentially expressed gene ZmCOI6.10 showed a close similarity to the plasma membrane $\mathrm{Ca}^{2+}$-ATPase. Changes in the cytosolic calcium concentration play a prominent role in signal transduction. It has been demonstrated that a wide array of stresses 
are accompanied by transient changes in the concentration of cytosolic free calcium [8,9]. The $\mathrm{Ca}^{2+}$-ATPase translocates calcium from the cytosol out of the cell or into organelles by using the energy from the hydrolysis of ATP. It is essential for the cell that the excess of $\mathrm{Ca}^{2+}$ is removed from the cytosol after a $\mathrm{Ca}^{2+}$-signal to bring the cell back to a resting state.

The induction of many, but not all, coldresponsive genes identified in various plant species are regulated through cis-elements like the C-repeat/dehydration-responsive elements (CRT/DRE) and the abscisic acid (ABA)responsive element. The cold-induced ZmCOI6.20 gene showed a close similarity to the DREB2 of millet, rice and Arabidopsis, but was clearly distinct from the DREB1A of maize. In Arabidopsis, the CBF/DREB transcription factors belong to a small gene family consisting of three sub-groups with CBF/DREB1 members being specifically induced by cold. In contrast, DREB2 transcription factors were induced by drought, $\mathrm{NaCl}$ and abscisic acid but not by cold [1]. Therefore, the induction of the DREB2-like gene, ZmCOI6.20, might be caused by a coldinduced drought stress, especially because the plants showed symptoms of wilting.

The ZmCOI6.21 gene was very similar to a rice ERF3 gene, which also belongs to the family of AP2/ERF transcription factors. The putative ZmCOI6.21 protein was characterised by an ERF-associated amphiphilic repression (EAR) motif which is conserved in the class II ERFs. In contrast to the CBF/DREB transcription factors, the class II ERFs have been shown to be active repressors of stressresponsive gene expression. The parallel induction of an activator (ZmCOI6.20) and repressor (ZmCOI6.21) of transcription, which both regulate GCC-box-dependent transcription, seems at first to be contradictory. This was, however, also observed in Arabidopsis under abiotic stress [3] and will be discussed in greater detail in the separate article.

Besides the cold-induced expression of genes, those proteins are involved in the cellular signalling and regulation of transcription; low temperature increased the transcripts of polypeptides known to be involved in the systemic response. One stress-induced molecule is jasmonic acid (JA). The 12-oxo-phytodienoic acid (OPDA) is the biosynthetic precursor of jasmonic acid (JA) and OPDA originates from linolenic acid by oxidative cyclization. The reduction of released OPDA by oxophytodienoic acid reductase (OPR1-3), which shows strong similarity with the deduced amino acid sequence of $\mathrm{ZmCOI6.12,} \mathrm{has} \mathrm{been}$ suggested to be the rate-limiting step in the JA biosynthesis [8]. In Arabidopsis, transient changes in the mRNA level of $O P R 1$ and $O P R 2$, two closely related genes encoding 12oxophytodienoic acid-10, 11-reductases, were observed in response to wounding, UV-C illumination as well as to heat and cold stress [10]. However, the significance of transcriptional activation of the $O P R$ gene remains unclear since the induction at the protein level was observed in Arabidopsis for OPR 3 but not for OPR1 and OPR2. ZmCOI6.12 was more similar to OPR2 than to OPR3.

Three of the differentially expressed genes encode enzymes involved in photosynthetic $\mathrm{CO}_{2}$ -fixation. One of these genes is NADP malic enzyme, which is part of the $\mathrm{C}_{4^{-}}$cycle and is nuclear encoded, while the other, ribulose bisphosphate carboxylase (large subunit), is part of the $\mathrm{C}_{3}$-cycle and is encoded in the chloroplast. The cold-susceptibility of certain $\mathrm{C}_{4}$-cycle enzymes is considered to be the limiting factor for the establishment of $\mathrm{C}_{4}$-plants under cold conditions. There is also evidence that the capacity of Rubisco is a major ratelimiting step during photosynthesis in $\mathrm{C}_{4}$-plants. The third protein, phosphoribulokinase, catalyses the phosphorylation of ribulose-5phosphate to ribulose-1,5-bisphosphate, the substrate for Rubisco. The role of phosphoribulokinase during environmental stress is largely unknown. Its increased expression indicates that it might play an important role during cold stress. However, an increase in the amount of transcript will not necessarily result in a higher activity of these enzymes, especially since it was shown that photosynthetic $\mathrm{CO}_{2}$ - fixation in maize leaves at optimal temperature conditions shows a sharp decrease after one day at $6 \square \mathrm{C}[7]$.

The deduced gene product of $\mathrm{ZmCOI6.3}$ showed considerable similarity to a hydroxyproline-rich glycoprotein. These groups 
of protein are often induced by stress (wounding, elicitors and infection) during early development (root and leaf). Proline-rich proteins (PRPs) in the plant are expressed in response to many external factors. For example, the SbPRP gene in soybean was induced by salt stress, drought stress, salicylic acid treatment and virus infection, while Wcor518 in Triticum aestrivum, PRP in Brassica napus and MsaCIC in alfalfa were cold-regulated. MsPRP2 in Medicago sativa was salt-inducible, while PRP in Lycopersicon chilense was negatively regulated by drought stress [5].

The hydrophobic protein LTI6b in rice, whose DNA sequence $(O s L t i 6 b)$ is very similar

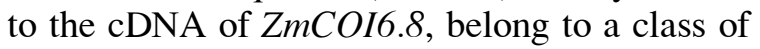
low-molecular-weight hydrophobic proteins involved in maintaining the integrity of the plasma membrane under cold, dehydration and salt stress conditions. Like OSLTI6b, the homologue maize LTI6b protein is characterised by two potential transmembrane helices covering most of the polypeptide length.

A gene ( $\mathrm{ZmCOI6.19)}$ homologue for a selenium-binding protein (SBP) was found in the cDNA library when exposed to $6 \square \mathrm{C}$ for 48 hours. Selenium is known to be incorporated into proteins as selenocysteine or selenomethionine. The function of SBP in plants is unknown. Recently, an SBP gene was obtained from ESTs of a moss treated with exogenous ABA. The drought- and salt-induced expression of an SBP gene in sunflower also indicates its function in response to abiotic stress.

The deduced $\mathrm{ZmCOI6.14}$ gene product was similar to SHAGGY-like kinases, which are involved in plant response to stress. While SHAGGY-like kinase, namely AtSK22, conferred resistance to $\mathrm{NaCl}$ in Arabidopsis, another SHAGGY-like homologue, WIG, responded to wounding in alfalfa (Medicago sativa). As in the animal kingdom, the roles of SHAGGY-like enzymes in plants are numerous [2].

The two-component response regulator-like PRR95 is very similar to the ZmCOI6.7deduced protein contain a CCT motif. The CCT motif is about 45 amino acids long and contains a putative nuclear localization signal within the second half of the CCT motif. The CCT
(CONSTANS, CO-like and TOC1) domain is a highly conserved basic module of about 43 amino acids, which is found near the C-terminus of the plant proteins usually involved in light signal transduction. These ARR (Arabidopsis response regulator homologues) proteins control the photoperiodic flowering response and seem to be one of the components of the circadian clock. The expression of several members of the ARR-like family is controlled by the circadian rhythm.

In addition to $\mathrm{ZmCOI6.4,} \mathrm{ZmCOI6.1}$ was similar to the gene sequence of a hypothetical protein of rice. The latter was highly replicated in the subtracted cDNA library and, therefore, may play an important role in the response of maize to low temperature.

The genes described here have never been mentioned being involved in the cold response of maize. They present new possibilities for elucidating the response pathways of this crop to cold and other stresses. These genes code for a wide variety of functions, from perception of stress and its signalling components to transcriptional modulators and to synthesis of osmolytes. The 18 independent cold-induced genes were grouped in six categories based on their function. The first group: linked to photosynthesis are ZmCOI6.5 (ZmPRK), ZmCOI6.9 (ZmMe1), ZmCOI6.15 (ZmrbcL) and $\mathrm{ZmCOI6.16}$ suggesting a remodelling of the photosynthesis to adapt to changed growth conditions to reduce waste of resources. The second group: related to signalling and regulation of gene transcription is including $\mathrm{ZmCOI6.2,}$ ZmACA1, ZmCOI6.14, ZmDREB2A and ZmERF3 suggesting the role of signal transduction of stimuli into the cell for a response and as a result changes in transcription by transcription factors. The third group: stress

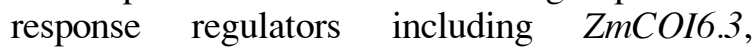
$\mathrm{ZmCOI6.8}$ and $\mathrm{ZmCOI6.19}$. The fourth group: $\mathrm{ZmCOI6.12}(\mathrm{ZmOPRl})$ is associated with the systemic response to stress. Regulation of metabolism including $\mathrm{ZmCOI6.4,} \mathrm{ZmCOI6.6}$ and $\mathrm{ZmCOI6.13}$ is the fifth group. The sixth group contains genes that codes for proteins with unknown function. Their further characterization will be the focus of the separate article. 


\section{REFERENCES}

1. Browse J. \& Xin Z., 2001: Current Opinion in Plant Biology, 4: 241-246.

2. Charrier B. et al., 2002: Plant Physiology, 130: $577-90$.

3. Fujimoto S. Y. et al., 2000: Plant Cell, 12: 393-404.

4. Chinnusamy V., Zhu J. and Kang J. Z., 2007: Trends in Plant Science, 12(10): 444451.

5. He C.Y., Zhang J. S. \& Chen S. Y., 2002: Theoretical and Applied Genetics, 104: 1125-1131.

6. Knight H., Knight M. R., 2001: Trends Plant Science, 6: 262-267.

7. Leipner J., Fracheboud Y. \& Stamp P., 1999: Environmental and Experimental Botany, 42: 129-139.
8. Rentel M. C. and Knight M. R., 2004: Plant Physiology, 135:1471-1479.

9. Sanders D., Brownlee C. and Harper J. F., 1999: Plant Cell, 11: 691-706.

10. Schaller F., 2001. Journal of Experimental Botany, 52:11-23.

11. Seki M. et al., 2002: Plant Journal, 31: 279292.

12. Thomashow M. F., 1999: Annual Review of Plant Physiology and Plant Molecular Biology, 50:571-599.

13. Zhang F. L. et al., 2008: Plant Science, 174: $510-518$.

14. Zheng J. et al., 2004: Plant Molecular Biology, 55: 807-823.

15. Wang C. R. et al., 2008: Planta, 227: 11271140.

16. Wu W. et al., 2008: Euphytica, 159: 17-25.

\title{
PHÂN LẬP CÁC GEN QUY ĐỊNH TÍNH CHỐNG CHỊU VớI ĐIỀU KIỆN MÔI TRƯờ SỐNG BẤT LợI BẦNG KỸ THUẬT PCR-SELECT CDNA SUBTRACTION Ở CÂY NGÔ (ZEA MAYS L.)
}

\author{
THUY HA NGUYEN, JÜRG LEIPNER, \\ PETER STAMP, ORLENE GUERRA-PERAZA
}

\section{TÓM TẮT}

Điều kiện môi trường sống bất lợi (khô hạn, lạnh, nóng, mặn...) ảnh hưởng lớn đến sinh trưởng, phát triển và năng suất cây trồng. Để sống sót trước điều kiện bất lợi này, cây ngô nói riêng và cây trồng nói chung phải có một loạt những thay đổi về sinh lý, sinh hoá và phân tử, ví dụ như sự thích nghi của bộ máy quang hợp, thay đổi thành phần lipid của màng tế bào, gia tăng hàm lượng canxi thẩm thấu và hoạt động của chuỗi các enzyme kinase phụ thuộc canxi, tích luỹ các chất chống đông lạnh (cryoprotectants), tổng hợp các chất thẩm thâu (compatible osmolytes) và các chất chống oxi hoá (antioxidant). Những thay đổi này là kết quả của sự tăng lên hay giảm đi về sự biểu hiện của gen ở mức độ phiên mã. Việc xác định chức năng của gen liên quan đến khả năng chống chịu ở mức độ phiên mã sẽ giúp chúng ta hiểu thêm cơ sở phân tử về phản ứng của ngô trước điều kiện sống bất lợi (cơ chế phản ứng của cây, những gien/nhóm gien nào tham gia vào quá trình phản ứng) và giúp chúng ta làm chủ được việc chọn tạo giống cây trồng mới có khả năng chống chịu với điều kiện sống bất lợi.

Bằng kỹ thuật PCR-Select cDNA Subtraction (hay còn gọi là phương pháp SSH) tiến hành trên mẫu lá ngô dòng DH7 xử lý ở nhiệt độ $6 \square \mathrm{C}$, chúng tôi đã thu 18 gen có biểu hiện cao trong điều kiện lạnh. Các gen này được chia thành 6 nhóm dựa vào chức năng của chúng. Sự biểu hiện cao của 18 gen này còn được kiểm chứng bằng phản ứng RT-PCR.

Trình tư nucleotide của các gen này cũng đã được đăng ký bản quyền tại Genebank với các mã số $\mathrm{t}$ ừ DQ078760 - DQ078778.

Ngày nhận bài: 30-11-2007 